Rev. Int. Contam. Ambie. 36 (3) 667-676, 2020

https://doi.org/10.20937/RICA.53565

\title{
TRACE METALS IN TWO WILD POPULATIONS OF THE SQUALID CALLISTA CLAM (Megapitaria squalida) IN THE SOUTHEASTERN GULF OF CALIFORNIA, MEXICO
}

Metales traza en dos poblaciones silvestres de la almeja callista escuálida (Megapitaria squalida) en el sureste del Golfo de California, México

\section{Carlos Humberto SEPÚLVEDA ${ }^{1}$, Andrés Martín GÓNGORA-GÓMEZ ${ }^{1}$, Sandra PÉREZ-ÁLVAREZ ${ }^{2}$, Hervey RODRÍGUEZ-GONZÁLEZ ${ }^{1}$, Norma Patricia MUÑOZ-SEVILLA ${ }^{3}$, Brenda Paulina VILLANUEVA-FONSECA ${ }^{4}$, Juan Antonio HERNÁNDEZ-SEPÚLVEDA ${ }^{5}$ and Manuel GARCÍA-ULLOA GÓMEZ ${ }^{1 *}$}

${ }^{1}$ Instituto Politécnico Nacional, Centro Interdisciplinario de Investigación para el Desarrollo Integral RegionalUnidad Sinaloa, Departamento de Acuacultura, A las Glorias, San Juachin, 81101 Guasave, Sinaloa, México

${ }^{2}$ Facultad de Ciencias Agrícolas y Forestales, Universidad Autónoma de Chihuahua, km 2.5 carretera DeliciasRosales, campus Delicias, 33000 Ciudad Delicias, Chihuahua, México

${ }^{3}$ Instituto Politécnico Nacional, Centro Interdisciplinario de Investigaciones y Estudios sobre el Medio Ambiente y Desarrollo, 30 de Junio de 1520 s/n, La Laguna Ticomán, 07340 Ciudad de México, México

${ }^{4}$ Universidad Autónoma de Occidente, Campus Guasave, Avenida Universidad s/n, Flamingos, 81048 Guasave, Sinaloa, México

${ }^{5}$ Instituto Politécnico Nacional, Centro Interdisciplinario de Investigación para el Desarrollo Integral RegionalUnidad Sinaloa, Departamento de Medio Ambiente, A las Glorias, San Juachin, 81101 Guasave, Sinaloa, México

*Author for correspondence: turbotuag@hotmail.com

(Received: March 2019; accepted: November 2019)

Key words: toxicology, chocolata clam, metals bioaccumulation, sediments, Sinaloa

\begin{abstract}
The squalid callista clam (Megapitaria squalida) is a popular raw seafood item for human consumption; however, as a filter feeder, this clam accumulates heavy metals from natural and anthropogenic sources. The concentrations of copper $(\mathrm{Cu})$, cadmium $(\mathrm{Cd})$, chromium $(\mathrm{Cr})$, nickel $(\mathrm{Ni})$, lead $(\mathrm{Pb})$, zinc $(\mathrm{Zn})$, arsenic $(\mathrm{As})$, and mercury $(\mathrm{Hg})$ in sediments and the soft tissues of M. squalida from two sites on the southeastern coast of the Gulf of California, Mexico, were evaluated from April 2016 to April 2017 on a monthly basis. The metal concentrations in sediments from both sites did not exceed the Mexican and international regulations. Concentrations of $\mathrm{Cd}$ and $\mathrm{Pb}$ in the clams from Altata bay (2.49 and $5.68 \mu \mathrm{g} / \mathrm{g} \mathrm{dw}$, respectively) and Agiabampo bay (2.38 and $5.54 \mu \mathrm{g} / \mathrm{g} \mathrm{dw}$, respectively) exceeded the permissible limits recommended by Mexican sanitary regulations, thus representing a threat to human health. The higher values of $\mathrm{Cd}, \mathrm{As}$, and $\mathrm{Hg}$ obtained for the biota sediment accumulation factor in both sampling areas indicate that squalid callista is a strong accumulator of these metals. The metal burdens in sediments and M. squalida soft tissues are influenced by chemicals from agriculture and aquaculture, as well as urban sewage disposal near both sites. This study brings useful information on metal bioaccumulation in one of the most important commercial clam species on the Pacific coast.
\end{abstract}

Palabras clave: toxicología, almeja chocolata, bioacumulación de metales, sedimentos, Sinaloa 


\section{RESUMEN}

La almeja callista escuálida (Megapitaria squalida) es un marisco popular que se consume crudo, pero por ser filtrador, puede acumular metales pesados de fuentes naturales y antrópicas. En el presente trabajo se evaluaron, de abril de 2016 a abril de 2017, las concentraciones mensuales de cobre $(\mathrm{Cu})$, cadmio $(\mathrm{Cd})$, cromo $(\mathrm{Cr})$, níquel $(\mathrm{Ni})$, plomo $(\mathrm{Pb})$, zinc $(\mathrm{Zn})$, arsénico (As) y mercurio $(\mathrm{Hg})$ en sedimentos y tejidos blandos de $M$. squalida de dos sitios de la costa sureste del Golfo de California, México. Los niveles de metales en los sedimentos de ambos sitios no excedieron las regulaciones mexicanas e internacionales. Las concentraciones de $\mathrm{Cd}$ y $\mathrm{Pb}$ en las almejas de la bahía de Altata ( 2.49 y $5.68 \mu \mathrm{g} / \mathrm{g}$ ps, respectivamente) y la bahía de Agiabampo (2.38 y $5.54 \mu \mathrm{g} / \mathrm{g}$ ps, respectivamente) sí excedieron los límites permisibles recomendados por las regulaciones sanitarias mexicanas, lo que representa una amenaza para la salud humana. El factor de acumulación de sedimentos en la biota para las dos áreas muestreadas indica que la almeja callista escuálida es un acumulador fuerte de $\mathrm{Cd}$, As y $\mathrm{Hg}$. Las concentraciones metálicas en los sedimentos y los tejidos blandos de $M$. squalida están influenciadas por los productos químicos utilizados en la agricultura y la acuicultura, así como por el suministro de aguas residuales urbanas cercanas a ambos sitios. Este estudio brinda información útil sobre la bioacumulación de metales en una de las especies de almejas comerciales más importantes de la costa del Pacífico.

\section{INTRODUCTION}

Trace metals reach coastal regions through continental runoff and atmospheric transport by natural and anthropogenic causes (Abdel-Ghani 2015). Nevertheless, they can accumulate at high concentrations in both the aquatic environment and marine organisms due to sewage disposal from human activities such as mining, livestock, poultry, agriculture, and aquaculture. Hazardous pollutants in wastes from anthropogenic activities are discharged into local irrigation systems and from there to estuaries and coastal ecosystems (Rainbow 2002).

Occupying the second trophic level of aquatic ecosystems, sessile filter-feeding bivalve mollusks inevitably accumulate high levels of metals in their soft tissues, representing a danger for human consumption. Marine bivalves feed selectively, filtering large volumes of seawater through their gills (Silvester et al. 2005) with which they trap suspended materials and sediments, phytoplankton, fecal pellets, detritus, and high molecular weight substances (Liu and Deng 2007 ) that are eventually ingested. Thus, metals associated with the aqueous phase, food, and sediments accumulate in the shells (Cravo et al. 2002) and soft tissues of these organisms (Góngora-Gómez et al. 2018).

Due to their sensitivity and rapid response to pollutants, bivalves such as mussels and oysters (Bray et al. 2015) are used as biomonitors of metal contamination in aquatic systems (Kanthai et al. 2014), the bioavailability of contaminants, and the degree of pollution. To a lesser extent, clams also serve as sentinel organisms for marine eco-toxicological tests to ensure coastal water quality with respect to metals. For instance, Bendell (2009) performed cadmium analysis on oysters, mussels, clams, and scallops sampled from commercial and natural sources on the west coast of British Columbia, Canada, and Kehrig et al. (2006) reported the levels of methyl and total mercury in mussels, oysters, and clams from two estuaries in Rio de Janeiro, Brazil. In both studies, mussels and oysters showed higher metal accumulation than clams and scallops. The latter two are part of the sedentary non-sessile benthic fauna for which metal accumulation levels strongly depend on the metals associated with particulates that settle in bottom sediments (Inengite et al. 2010) and on the specific bioavailability of different trace metals (Ferreira et al. 2004).

Megapitaria squalida, commonly known as the squalid callista clam, represents one of the most important bivalve species on the southeastern coast of the Gulf of California, Mexico (Arellano-Martínez et al. 2006). This clam, which is naturally distributed from Baja California to Peru, digs in sandy clay sediments in the intertidal zone to depths of approximately $160 \mathrm{~m}$ (Coan and Valentich-Scott 2012). It is a popular raw seafood for human consumption with wild banks located in coastal lagoon systems in the southeastern Gulf of California, where intense anthropogenic activities also occur. Thus, these areas are under permanent pressure and the trace metal burdens in M. squalida, consequently, represent a potential risk for human health. 
Due to the significance of copper $(\mathrm{Cu})$, cadmium $(\mathrm{Cd})$, chromium $(\mathrm{Cr})$, nickel $(\mathrm{Ni})$, lead $(\mathrm{Pb})$, arsenic (As), zinc $(\mathrm{Zn})$, and mercury $(\mathrm{Hg})$ to public health (WHO 1996), their high degree of toxicity (ATSDR 2006), and their routine association with human activities around the sample sites (Gómez-Arroyo et al. 2013), the levels of these metals were assessed both in sediments and in the soft tissues of M. squalida from two locations on the southeastern coast of the Gulf of California during 13 consecutive months. The levels were evaluated based on national and international permissible levels for human consumption.

\section{MATERIALS AND METHODS}

\section{Study area}

Two sites along the north central coast of Sinaloa, Mexico, with different sources of pollution were selected for this study. Site 1 was located in Altata Bay $\left(24^{\circ} 20^{\prime}-24^{\circ} 35^{\prime} \mathrm{N}, 107^{\circ} 20^{\prime}-107^{\circ} 55^{\prime} \mathrm{W}\right)$ in the Navolato municipality, which is a marine environment with an outlet providing a permanent connection to the Gulf of California. The main tributary of Altata Bay is the Culiacan valley, an extensive agricultural area where the primary economic activities are centered on El Dorado, Rosales, and La Primavera sugar mills, from which wastes are routed to irrigation district No. 10 , and subsequently discharged directly into the bay (Gaxiola 2003). The main anthropogenic activities in this region are agriculture, fishing, urbanization, and tourism (Frías-Espericueta et al. 2014). Site 2 is located in Agiabampo bay $\left(26^{\circ} 06^{\prime}-26^{\circ} 32^{\prime} \mathrm{N}, 109^{\circ}\right.$ $01^{\prime}-109^{\circ} 20^{\prime} \mathrm{W}$ ) in the Ahome municipality, between the El Fuerte and Mayo rivers with a permanently open mouth to the Gulf of California which allows the seawater flux in the bay and is surrounded by sand bars. This area is used for agriculture (Carrizo and Fuerte-Mayo drainages) and aquaculture (ColínRangel 2007).

\section{Trace metal analysis}

From April 2016 to April 2017, approximately $500 \mathrm{~g}$ of sediment were collected monthly from each site following standard USEPA (2001) procedures, kept in acid-cleaned plastic bottles, and transported to the Laboratorio de Malacología of the Centro Interdisciplinario de Investigación para el Desarrollo Integral Regional, Unidad Sinaloa, Instituto Politécnico Nacional (IPN-CIIDIR-Sinaloa), where they were frozen and stored. The frozen samples were freeze dried at low temperature and high vacuum $\left(-53^{\circ} \mathrm{C}\right.$ and $133 \times 10^{-3} \mathrm{mBar}$, respectively) for three days to remove the moisture, then passed through a 2 $\mathrm{mm}$ sieve and $1 \mathrm{~g}$ of the sample was placed in acidcleaned glass bottles prior to digestion.

To limit the effect of size as a source of variation, a total of 24 clams of approximately equal length (55.76 \pm 5.09 and $61.58 \pm 5.19 \mathrm{~mm}$, for Altata and Agiabampo, respectively) were hand collected monthly from each site, thoroughly rinsed with seawater to remove adhered algae and sediments, stored on ice in clear polyethylene bags, and transported to IPNCIIDIR-Sinaloa, following SSA (1994) methods for cleaning, sacrificing, and shucking. The soft tissues were removed from the clam shells using a stainlesssteel knife and thoroughly washed with double distilled water. Samples were subsequently freeze dried $-53^{\circ} \mathrm{C}$ and $133 \times 10^{-3} \mathrm{mBar}$ ), pulverized, and homogenized by quartering; thus, all fractions of the sample were equal in composition. Dry weights (dw) of the samples were obtained by using a digital analytical balance (EA Adam, $0.001 \mathrm{~g}$ ). All chemicals used in this study were GR grade (Merk Company). All materials were first cleaned with nitric acid $(10 \%)$ for a $24 \mathrm{~h}$ period then rinsed with double distilled water.

To analyze the metal burdens, the clam soft tissue samples (1-1.5 g dw) were digested with $3 \mathrm{ml}$ of $70 \% \mathrm{NHO}_{3}$ and $0.5 \mathrm{ml}$ of $30 \% \mathrm{H}_{2} \mathrm{O}_{2}$ using a microwave digestor (Parr Physica Multiwave Six Place) at $300 \mathrm{~W}$ for $5 \mathrm{~min}$, then at $600 \mathrm{~W}$ for $10 \mathrm{~min}$, which proved to be satisfactory for an adequate digestion of samples. Digestions were performed and stored until metal analysis as described by Góngora-Gómez et al. (2018).

All metals were analyzed at the Laboratorio de Análisis y Monitoreo Ambiental of the Centro Interdisciplinario de Investigaciones y Estudios sobre el Medio Ambiente y Desarrollo (IPN-CIIEMAD); the concentrations of As and $\mathrm{Hg}$ were analyzed by atomic absorption spectroscopy (AAS) with cold vapor generation (Perkin-Elmer, Analyst 100, coupled MHS $15)$, and the rest of metals ( $\mathrm{Cu}, \mathrm{Cd}, \mathrm{Cr}, \mathrm{Ni}, \mathrm{Pb}$, and $\mathrm{Zn})$ by using flame AAS (Perkin-Elmer, PinAAcle 900T). For quality assurance, the standard reference material (1566b for oysters, available at the National Bureau of Standards, NBS), reagent blanks, and duplicate samples were run with each digest. Mean recovery values were $\mathrm{Cu}=93.03 \%, \mathrm{Cd}=99.11 \%, \mathrm{Cr}=91.25 \%$, $\mathrm{Ni}=96.34 \%, \mathrm{~Pb}=97.72 \%, \mathrm{Zn}=99.78 \%$, $\mathrm{As}=95.30 \%$ and $\mathrm{Hg}=97.29 \%$. Heavy metal concentrations in sediment and soft tissue of clams were reported as dry weight $(\mu \mathrm{g} / \mathrm{g})$. The detection limits for $\mathrm{Cu}, \mathrm{Cd}, \mathrm{Cr}, \mathrm{Ni}, \mathrm{Pb}, \mathrm{Zn}$, As and $\mathrm{Hg}$ were $0.032,0.008$, $0.032,0.046,0.100,0.0002,0.039$ and $0.0003 \mu \mathrm{g} / \mathrm{g}$ $\mathrm{dw}$, respectively. 
The biota sediment accumulation factor (BSAF) indicates the efficiency of metal bioaccumulation in clam soft tissues regarding the concentration of metal in sediment; it was calculated for each site following Thomann et al. (1995):

$\mathrm{BSAF}=$ concentration of metal in clam/ concentration of metal in sediment

\section{Statistical analyses}

All data were tested for normality, and statistical tests were selected accordingly. Descriptive statistics (mean, standard deviation, maximum, and minimum) were used to evaluate metal concentrations for each month and site. The coefficients of variation (CV) for the metal burdens were used to test the reliability of data. Student t-test was used to compare metal concentrations between sediments and clams from each site, and between sediments from both sites and clams from both sites. Spearman's rank order correlations were computed for the heavy metal levels in the sediments and clams from each site. Statistical analyses were performed $(\mathrm{p}<0.05)$ using the STATISTICA (StatSoft, Tulsa, OK, USA) software package.

\section{RESULTS}

Metal levels in the sediments and clams from Altata and Agiabampo varied spatially (Table I). Zn had the highest monthly and mean values in both sediments (46.55 and $31.07 \mu \mathrm{g} / \mathrm{g} \mathrm{dw}$ for Altata and Agiabampo, respectively) and clams (51.39 and $46.81 \mu \mathrm{g} / \mathrm{g}$ $\mathrm{dw}$ for Altata and Agiabampo, respectively). The CV values for metals fluctuated from $9.67 \%$ for $\mathrm{Cu}$ in sediments to $212.50 \%$ for $\mathrm{Cr}$ in clams at Altata Bay

TABLE I. METAL CONCENTRATIONS (MEAN \pm STANDARD DEVIATION, $\mu \mathrm{g} / \mathrm{g} \mathrm{dw}$ ) IN SEDIMENT AND CLAMS FROM ALTATA AND AGIABAMPO BAYS, SINALOA, MEXICO

\begin{tabular}{|c|c|c|c|c|}
\hline & \multicolumn{2}{|c|}{ Altata bay } & \multicolumn{2}{|c|}{ Agiabampo bay } \\
\hline & Sediment & Clam & Sediment & Clam \\
\hline $\mathrm{Cu}$ & $4.34 \pm 4.42$ & $6.22 \pm 1.24$ & $3.41 \pm 0.78$ & $5.56 \pm 1.27$ \\
\hline $\mathrm{Cr}$ & $6.25 \pm 1.25$ & $0.08 \pm 0.17$ & $5.66 \pm 1.85$ & $0.20 \pm 0.21$ \\
\hline $\mathrm{Cd}$ & $0.15 \pm 0.14$ & $2.48 \pm 0.37$ & $0.06 \pm 0.12$ & $2.38 \pm 0.38$ \\
\hline $\mathrm{Ni}$ & $6.16 \pm 1.09$ & $3.50 \pm 0.54$ & $4.25 \pm 1.71$ & $2.47 \pm 0.84$ \\
\hline $\mathrm{Pb}$ & $9.82 \pm 2.36$ & $5.68 \pm 1.80$ & $9.06 \pm 1.93$ & $5.54 \pm 1.58$ \\
\hline As & $0.88 \pm 0.23$ & $4.47 \pm 0.37$ & $0.99 \pm 0.39$ & $4.52 \pm 1.36$ \\
\hline $\mathrm{Zn}$ & $46.55 \pm 9.56$ & $51.39 \pm 2.34$ & $31.14 \pm 9.04$ & $46.81 \pm 3.05$ \\
\hline $\mathrm{Hg}$ & $0.06 \pm 0.02$ & $0.28 \pm 0.08$ & $0.07 \pm 0.03$ & $0.32 \pm 0.10$ \\
\hline
\end{tabular}

and from $6.51 \%$ for $\mathrm{Zn}$ in clams to $200 \%$ for $\mathrm{Cd}$ in sediments at Agiabampo Bay.

With the exception of $\mathrm{Cd}$ and $\mathrm{Hg}$ in sediments, the ranking of metal concentrations presented the same order that in sediments $(\mathrm{Zn}>\mathrm{Pb}>\mathrm{Cr}>\mathrm{Ni}>\mathrm{Cu}>$ $\mathrm{As}>\mathrm{Cd}>\mathrm{Hg}$ at Altata and $\mathrm{Zn}>\mathrm{Pb}>\mathrm{Cr}>\mathrm{Ni}>\mathrm{Cu}$ $>\mathrm{As}>\mathrm{Hg}>\mathrm{Cd}$ at Agiabampo) and clams $(\mathrm{Zn}>\mathrm{Cu}$ $>\mathrm{Pb}>\mathrm{As}>\mathrm{Ni}>\mathrm{Cd}>\mathrm{Hg}>\mathrm{Cr}$ at Altata and $\mathrm{Zn}>$ $\mathrm{Cu}>\mathrm{Pb}>\mathrm{As}>\mathrm{Ni}>\mathrm{Cd}>\mathrm{Hg}>\mathrm{Cr}$ at Agiabampo). Only the $\mathrm{Zn}$ levels in sediments and clams from Altata were similar ( $p=0.08$, Table II).

TABLE II. COMPARISON OF METAL CONCENTRATIONS BETWEEN SEDIMENTS AND CLAMS IN EACH SITE

\begin{tabular}{lrlrrr}
\hline & \multicolumn{2}{c}{ Altata bay } & & \multicolumn{2}{c}{ Agiabampo bay } \\
\cline { 2 - 3 } \cline { 5 - 6 } & \multicolumn{1}{c}{$\mathrm{t}$} & $\mathrm{p}$ & & $\mathrm{t}$ & $\mathrm{p}$ \\
\hline $\mathrm{Cu}$ & -5.14 & $0.00^{*}$ & & 3.36 & $0.00^{*}$ \\
$\mathrm{Cr}$ & 17.59 & $0.00^{*}$ & & 10.36 & $0.00^{*}$ \\
$\mathrm{Cd}$ & -20.33 & $0.00^{*}$ & & -19.04 & $0.00^{*}$ \\
$\mathrm{Ni}$ & 4.69 & $0.00^{*}$ & & 3.97 & $0.00^{*}$ \\
$\mathrm{~Pb}$ & 3.96 & $0.00^{*}$ & & 4.98 & $0.00^{*}$ \\
$\mathrm{As}$ & -29.64 & $0.00^{*}$ & & -8.82 & $0.00^{*}$ \\
$\mathrm{Zn}$ & -1.77 & 0.08 & & -5.62 & $0.00^{*}$ \\
$\mathrm{Hg}$ & -9.45 & $0.00^{*}$ & -8.08 & $0.00^{*}$ \\
\hline
\end{tabular}

$\mathrm{t}$ : Student t-test, $\mathrm{p}$ : level of significance

*Significant differences, $\mathrm{p} \leq 0.05$

The concentrations of $\mathrm{Cu}, \mathrm{Ni}$, and $\mathrm{Zn}$ were significantly different $(\mathrm{p} \leq 0.05)$ between sediments from both sites and between clams from the two bays (Table III).

TABLE III. COMPARISON OF METAL CONCENTRATIONS IN SEDIMENTS AND CLAMS BETWEEN THE TWO SITES

\begin{tabular}{lrlrrl}
\hline & \multicolumn{2}{c}{ Sediment } & & \multicolumn{2}{c}{ Squalid callista } \\
\cline { 2 - 3 } \cline { 5 - 6 } & \multicolumn{1}{c}{$\mathrm{t}$} & $\mathrm{p}$ & & $\mathrm{t}$ & $\mathrm{p}$ \\
\cline { 2 - 3 } $\mathrm{Cu}$ & 32.83 & $0.00^{*}$ & & 17.40 & $0.00^{*}$ \\
$\mathrm{Cr}$ & 1.06 & 0.30 & & -1.26 & 0.23 \\
$\mathrm{Cd}$ & 1.96 & 0.07 & & 0.88 & 0.39 \\
$\mathrm{Ni}$ & 3.62 & $0.00^{*}$ & & 3.34 & $0.00^{*}$ \\
$\mathrm{~Pb}$ & 1.41 & 0.18 & & 0.20 & 0.83 \\
$\mathrm{As}$ & -0.81 & 0.43 & & 0.11 & 0.90 \\
$\mathrm{Zn}$ & 5.32 & $0.00^{*}$ & & 4.22 & $0.00^{*}$ \\
$\mathrm{Hg}$ & -0.88 & 0.39 & & -0.88 & 0.39 \\
\hline
\end{tabular}

$\mathrm{t}$ : Student t-test, $\mathrm{p}$ : level of significance

$*$ Significant differences, $\mathrm{p} \leq 0.05$ 
The metal rankings for sediments and clams from both sample sites indicate that $\mathrm{Zn}$ was the most abundant element with a concentration ranging from $31.07 \mu \mathrm{g} / \mathrm{g} \mathrm{dw}$ for Altata sediments to $51.39 \mu \mathrm{g} / \mathrm{g} \mathrm{dw}$ in Altata clams.

None of the metals studied surpassed the permissible limits in sediments (CCME 2003; SEMARNAT 2007) from both sites; however, some metal contents in clams did exceed permissible limits. $\mathrm{Cd}$ and $\mathrm{Pb}$ contents in clams from Altata (2.49 and $5.68 \mu \mathrm{g} / \mathrm{g} \mathrm{dw}$, respectively) and Agiabampo (2.38 and $5.54 \mu \mathrm{g} / \mathrm{g} \mathrm{dw}$, respectively) were higher than permitted by Mexican regulations ( 2 and $1 \mu \mathrm{g} / \mathrm{g} \mathrm{dw}$, respectively (SSA 1995, 2011).

At Altata, $\mathrm{Cd}$ and $\mathrm{Pb}$ were significantly correlated $(\mathrm{r}=0.55)$ in clams and correlations were found between $\mathrm{Ni}$ and $\mathrm{Cr}, \mathrm{Pb}$ and $\mathrm{Cr}, \mathrm{Pb}$ and $\mathrm{Ni}, \mathrm{Zn}$ and $\mathrm{Cr}$, and $\mathrm{Zn}$ and $\mathrm{Pb}(\mathrm{r}=0.63-0.93)$ in sediments. For Agiabampo, significant correlations were obtained for $\mathrm{Cd} / \mathrm{Cr}(\mathrm{r}=0.73), \mathrm{Pb} / \mathrm{Ni}(\mathrm{r}=0.76)$, and $\mathrm{Zn} / \mathrm{Cd}$ $(\mathrm{r}=0.72)$ in clams, and for $\mathrm{Ni} / \mathrm{Cr}(\mathrm{r}=0.65), \mathrm{Ni} / \mathrm{Cd}$ $(\mathrm{r}=0.65)$, and $\mathrm{Pb} / \mathrm{Cd}(\mathrm{r}=0.67)$ in sediments.

Overall, the BSAF for Altata and Agiabampo presented the following order: $\mathrm{Cd}>\mathrm{As}>\mathrm{Hg}>\mathrm{Cu}$ $>\mathrm{Zn}>\mathrm{Pb}>\mathrm{Ni}>\mathrm{Cr}$ and $\mathrm{Cd}>\mathrm{As}>\mathrm{Hg}>\mathrm{Cu}>\mathrm{Zn}$ $>\mathrm{Ni}>\mathrm{Pb}>\mathrm{Cr}$, respectively (Table IV). The clam soft tissues exhibited the highest levels of absorption capacity for $\mathrm{Cd}$ (10.75 and 7.07), As (5.42 and 5.25), $\mathrm{Hg}$ (4.83 and 5.04), $\mathrm{Cu}$ (1.44 and 1.74), and $\mathrm{Zn}$ (1.15 and 1.62) for Altata and Agiabampo, respectively.

TABLE IV. BIOTA SEDIMENT ACCUMULATION FACTOR (BSAF) OF Megapitaria squalida FROM ALTATAAND AGIABAMPO BAYS, SINALOA, MEXICO

\begin{tabular}{|c|c|c|}
\hline & Altata & Agiabampo \\
\hline $\mathrm{Cu}$ & $1.44 \pm 0.29$ & $1.74 \pm 0.70$ \\
\hline $\mathrm{Cr}$ & $0.01 \pm 0.03$ & $0.04 \pm 0.04$ \\
\hline $\mathrm{Cd}$ & $10.76 \pm 12.37$ & $7.08 \pm 15.16$ \\
\hline $\mathrm{Ni}$ & $0.59 \pm 0.14$ & $0.64 \pm 0.26$ \\
\hline $\mathrm{Pb}$ & $0.63 \pm 0.27$ & $0.64 \pm 0.21$ \\
\hline As & $5.42 \pm 1.52$ & $5.25 \pm 2.39$ \\
\hline $\mathrm{Zn}$ & $1.15 \pm 0.26$ & $1.63 \pm 0.49$ \\
\hline $\mathrm{Hg}$ & $4.83 \pm 1.21$ & $5.04 \pm 1.94$ \\
\hline
\end{tabular}

\section{DISCUSSION}

Due to the ecological and commercial importance, as well as the high consumption demand for different mollusk species in the study region, several biomonitoring studies focusing on heavy metal accumulation in a variety of bivalve species have been conducted and provide comparative data. Wild and cultivated oysters, pen shells, and clams have been used as biological monitors for heavy metals. For instance, Frías-Espericueta et al. (2008) obtained higher $\mathrm{Cu}$ $(21-73.2 \mu \mathrm{g} / \mathrm{g} \mathrm{dw})$ and $\mathrm{Cd}(1.8-7.2 \mu \mathrm{g} / \mathrm{g} \mathrm{dw})$ levels, but lower $\mathrm{Pb}(2.6-8.7 \mu \mathrm{g} / \mathrm{g} \mathrm{dw})$ burdens in a wild bank of the pleasure oyster (Crassostrea corteziensis) from the Altata bay. The Zn $(1-1.66 \mu \mathrm{g} / \mathrm{g} \mathrm{dw}), \mathrm{Cr}$ (0.4-1 $\mu \mathrm{g} / \mathrm{g} \mathrm{dw}), \mathrm{Ni}(0.33-2.3 \mu \mathrm{g} / \mathrm{g} \mathrm{dw}), \mathrm{Pb}(0.66-2$ $\mu \mathrm{g} / \mathrm{g} \mathrm{dw})$, and As (0.2-0.57 $\mu \mathrm{g} / \mathrm{g} \mathrm{dw})$ concentrations reported by Góngora-Gómez et al. (2018) in the muscle of the pen shell (Atrina maura) cultivated at a farm located between the two sample sites were lower than the levels we obtained for $\mathrm{Zn}$ (2.44-5.16 $\mu \mathrm{g} / \mathrm{g} \mathrm{dw}), \mathrm{Cr}(3.51-9.76 \mu \mathrm{g} / \mathrm{g} \mathrm{dw}), \mathrm{Ni}(2.49-8.55 \mu \mathrm{g} / \mathrm{g}$ $\mathrm{dw}), \mathrm{Pb}(6.68-14.45 \mu \mathrm{g} / \mathrm{g} \mathrm{dw})$, and As (0.4-1.82 $\mu \mathrm{g} / \mathrm{g}$ dw). Muñoz-Sevilla et al. (2017) registered variations of $\mathrm{Cu}(10.2-26.6 \mu \mathrm{g} / \mathrm{g} \mathrm{dw}), \mathrm{Cd}(0.8-3.8 \mu \mathrm{g} / \mathrm{g} \mathrm{dw})$, $\mathrm{Pb}(1.3-3.6 \mu \mathrm{g} / \mathrm{g} \mathrm{dw}), \mathrm{Zn}(57.2-219.4 \mu \mathrm{g} / \mathrm{g} \mathrm{dw})$, and $\mathrm{Hg}(0.02-0.11 \mu \mathrm{g} / \mathrm{g} \mathrm{dw})$ in Pacific oysters (C. gigas) cultivated near the Agiabampo bay. These variations can be attributed to differences in human activities around the study areas, latitude, environmental conditions, and the bivalve species studied.

Different baseline metal orders in sediments have been reported by Widmeyer and Bendell-Young (2008) in British Columbia, Canada $(\mathrm{Cu}>\mathrm{Zn}, \mathrm{Pb}>$ $\mathrm{Cd})$, Tarique et al. (2012) $(\mathrm{Pb}>\mathrm{Cu}>\mathrm{Cd}>\mathrm{Hg})$ in the Kuwait bay, and Jonathan et al. (2017) $(\mathrm{Zn}>\mathrm{Cr}>\mathrm{Ni}$ $>\mathrm{Cu}>\mathrm{Pb}>\mathrm{As}>\mathrm{Cd}>\mathrm{Hg}$ ) in the southwestern Gulf of California. In the case of Altata and Agiabampo, metal concentrations in sediments were affected by a number of factors, including sewage effluents from industry, urban sewage disposal, agricultural activities, and aquaculture farms close to the sample sites (PáezOsuna et al. 2003, Hernández-Cornejo et al. 2005, Muñoz-Sevilla et al. 2017); also, by the relationship between grain size and texture and metal adsorption that in this case favors degradation of organic matter by tidal mixing (Forrest and Creese 2006), as well as the natural erosion of the rocks, dissolution processes, and water runoff from upstream of the estuaries (Murray and Busty 2015). The external and natural inputs at each specific locality may help to understand the differences among the aforementioned results.

The metal bioaccumulation orders observed in $M$. squalida from both sites differed from those reported by Tarique et al. (2012) $(\mathrm{Zn}>\mathrm{Cu}>\mathrm{Cr}>\mathrm{Ni}>\mathrm{Hg}>$ $\mathrm{Cd}>\mathrm{Pb}$ ) and Mohammad et al. (2017) $(\mathrm{Zn}>\mathrm{Pb}>$ $\mathrm{Cu}>\mathrm{Cd}$ ) for the clams Amiantis umbonella in the Kuwait bay and Donax semistriatus in the Mediterranean Sea, respectively. Góngora-Gómez et al. 
(2017) analyzed the metal concentrations in oysters (C. gigas) cultivated in a lagoon system between Altata and Agiabampo, registering the following rank order of accumulation: $\mathrm{Zn}>\mathrm{Cu}>\mathrm{Cr}>\mathrm{Cd}>\mathrm{Ni}>$ $\mathrm{Pb}>\mathrm{As}>\mathrm{Hg}$, which is similar to those obtained by Osuna-Martínez et al. (2011) $(\mathrm{Zn}>\mathrm{Cu}>\mathrm{Cd}>\mathrm{Pb})$ and Vázquez-Boucard et al. (2014) $(\mathrm{Zn}>\mathrm{Cd}>\mathrm{Pb})$ for the same oyster species in the studied region.

Several biotic factors affect metal bioaccumulation in bivalve mollusks. Some trace metals like $\mathrm{Zn}$, $\mathrm{Na}$, and $\mathrm{Cu}$ are essential for tissue formation, metabolic physiology, cellular metabolism, and nutrient synthesis and metabolism (Barile 2008), but levels exceeding normal requirements can impair growth, reproduction, and general development. Jara-Marini et al. (2013) stated that $\mathrm{Cu}$ levels in adult oysters decreased during the post-spawning event, whilst Lango-Reynoso et al. (2010) registered variations in $\mathrm{Cd}$ accumulation during different reproductive stages. Páez-Osuna et al. (1995) concluded that concentrations of some metals vary seasonally with reproductive events and gonadal development after finding higher levels of $\mathrm{Cu}$ and $\mathrm{Zn}$ at the end of the reproductive cycle in oysters. These findings do not coincide with the results obtained in this study, since M. squalida from both sites did not show a normal seasonal pattern for bioaccumulation of the metals examined. On the other hand, no tools for evaluating clam reproductive phases were employed in this study, as this was not the goal of our research. In fact, no reports on the relationship between metal accumulation and reproduction of the squalid callista are available so far.

As with other bivalves, M. squalida is a popular raw dietary item not only in coastal areas of the Gulf of California, but also in cities where there is a high demand for this resource (Amezcua-Castro et al. 2015). However, only a few studies have been conducted on heavy metals in the squalid callista along the coasts of the Gulf of California. Méndez et al. (2006) analyzed $\mathrm{Pb}, \mathrm{Ni}, \mathrm{Cd}, \mathrm{Mn}, \mathrm{Zn}, \mathrm{Cu}$, and $\mathrm{Fe}$ levels in M. squalida from an apparently contamination-free site in the southwestern Gulf of California, and concluded that this clam should be consumed before the rainy season due to $\mathrm{Pb}$ and $\mathrm{Cd}$ accumulation. Cantú-Medellín et al. (2009) stated that some antioxidant defense mechanisms in M. squalida changed in response to the bioaccumulation degree of some metals, such as $\mathrm{Cd}, \mathrm{Pb}$, and Fe. Through morphometry and condition index, Yee-Duarte et al. (2017) concluded that health of the squalid callista clam in Santa Rosalía, Baja California Sur, evidenced negative physiological effects, possibly caused by contamination from metals produced by the local mining activity. Romo-Piñera et al. (2018) evaluated the total $\mathrm{Hg}$ concentration in the squalid callista, finding relatively low values of $\mathrm{Hg}(0.06-0.09 \mu \mathrm{g} / \mathrm{g} \mathrm{dw})$ in soft tissues that nonetheless represent a potential risk for human health.

These works were carried out in wild squalid callista populations from the southwestern Gulf of California. Only Frías-Espericueta et al. (2008) recorded metal contents $(\mathrm{Cd}, \mathrm{Cu}, \mathrm{Pb}$, and $\mathrm{Zn})$ in oysters, mussels, and clams from the Altata-Pabellones lagoon system (southeastern Gulf of California) and found differences in metal bioaccumulation during the rainy and dry seasons, and between the different bivalve species. They concluded that the inner mangrove swamp species (C. corteziensis and Mytella strigata) bioaccumulated higher levels of $\mathrm{Cd}$ and $\mathrm{Cu}$ than M. squalida, which inhabits areas under marine influence. This confirms the strong influence of habitat on metal bioaccumulation in different bivalve species, as well as the need for more research related to heavy metal accumulation in M. squalida from natural banks at the southeastern coast of the Gulf of California.

Since limits for $\mathrm{Zn}, \mathrm{Cu}, \mathrm{Cr}$, and Ni in soft tissue of clams have not yet been set in Mexico, the concentrations of these metals were compared with standards established in other countries. Zn (51.39 $\mu \mathrm{g} / \mathrm{g} \mathrm{dw})$ in M. squalida from Altata and $\mathrm{Hg}$ $(0.32 \mu \mathrm{g} / \mathrm{g} \mathrm{dw})$ in clams from Agiabampo surpassed the permissible limits established by the Ministry of Agriculture, Fisheries and Food (50 and $0.3 \mu \mathrm{g} / \mathrm{g}$ dw, respectively) in the UK (Sally et al. 1996). Cu, $\mathrm{Cd}$, and $\mathrm{Zn}$ burdens were lower than those reported by Frías-Espericueta et al. (2008) for M. squalida from Altata. However, Ni was lower than the level obtained by Méndez et al. (2006) in a wild population of squalid callista clam on the southwestern coast of the Gulf of California. Recently, Romo-Piñera et al. (2018) reported $\mathrm{Hg}$ at $0.05-0.09 \mu \mathrm{g} / \mathrm{g} \mathrm{dw}$ in soft tissues of $M$. squalida from La Paz bay, Baja California Sur, Mexico, which is lower than the Hg levels in both bays examined in the present study. The presence of high levels of $\mathrm{Cd}$ and $\mathrm{Pb}$ in clams from both places is associated to phosphate fertilizers used in agriculture (Jara-Marini et al. 2013) and aquaculture and industrial influxes from the region (Luoma and Rainbow 2005), respectively.

A strong association has been reported between particular groups of metals, suggesting a possible common source (García-Rico et al. 2001, Jonathan et al. 2017, Muñoz-Sevilla et al. 2017). It is reported that in approximately 200000 ha that surround the 
two studied regions, the agriculture of different grains and vegetables, such as corn, tomato, and beans, is practiced; thus, enormous amounts of agrochemicals containing $\mathrm{Cd}, \mathrm{Ni}$, and $\mathrm{Zn}$ are used in fertilizers (Páez-Osuna et al. 1993), insecticides, fungicides, and herbicides (Gómez-Arroyo et al. 2013). These heavy metals are eventually leached from the soil and transported to the coastal lagoon systems inhabited by these clams (Páez-Osuna and Osuna-Martínez 2015). This was confirmed by the correlations found in the sediments between $\mathrm{Ni} / \mathrm{Cr}, \mathrm{Pb} / \mathrm{Cr}, \mathrm{Pb} / \mathrm{Ni}, \mathrm{Zn} /$ $\mathrm{Cr}$, and $\mathrm{Zn} / \mathrm{Pb}$ at Altata, between $\mathrm{Ni} / \mathrm{Cr}, \mathrm{Ni} / \mathrm{Cd}$, and $\mathrm{Pb} / \mathrm{Cd}$ at Agiabampo, in the clam soft tissue between $\mathrm{Cd} / \mathrm{Pb}$ at Altata, and between $\mathrm{Cd} / \mathrm{Cr}, \mathrm{Pb} / \mathrm{Ni}$, and $\mathrm{Zn} /$ $\mathrm{Cd}$ at Agiabampo.

Since both sites are connected to irrigation districts, they receive agrochemicals not only from agriculture and livestock industries, but also from shrimp aquaculture ponds (Hernández-Cornejo et al. 2005), resulting in high contamination influxes to the estuaries in the study area. There are reports for decades ago that the lagoon systems near our sample sites is receiving tons of inorganic nitrogen, inorganic phosphorous, fungicides, pesticides, and herbicides from anthropogenic activities highlighting that their influxes would increase over time (Escobedo-Urías 2010, Gómez-Arroyo et al. 2013). The presence of $\mathrm{Pb}$ and $\mathrm{Cr}$ relationships in sediments and clams reflects the impact of untreated sewage discharges from the different (domestic, aquaculture, and agriculture) activities (Wong et al. 2007) and industrial complexes (sugar mills) in the region (Gaxiola 2003).

The BSAF orders in our study reflect the high absorption capacity of $\mathrm{Cd}$, $\mathrm{As}$, and $\mathrm{Hg}$; the moderate absorption capacity of $\mathrm{Cu}$ and $\mathrm{Zn}$, and the low absorption capacity of $\mathrm{Pb}, \mathrm{Ni}$, and $\mathrm{Cr}$ in the soft tissues of clams. Soto-Jiménez et al. (2001) mentioned that the degree of metal availability from sediments is partially due to the exchangeable carbonates and organic phases made available to the organisms by water currents. $\mathrm{Cd}$ had the highest biosediment accumulation factor values at both sites, but the $\mathrm{Cu}$ and Zn concentrations in sediments were lower, suggesting a higher rate of accumulation of these metals by M. squalida. $\mathrm{Pb}, \mathrm{Ni}$, and $\mathrm{Cr}$ were generally lower in the clam soft tissues than in sediments from both sites, suggesting that the clams' capacity to regulate these metals was not surpassed by the metal levels in sediment, as observed by Mohammad et al. (2017) in the clam D. semistriatus. For the rest of the metals evaluated, factors such as metal concentration in water and clam metabolism (Páez-Osuna et al.
1995), among other internal and external factors, may partially explain the BSAF reported here.

\section{CONCLUSIONS}

All metals assessed were found in sediment and M. squalida soft tissue from both sites, confirming the strong influence from the various anthropogenic activities present around both studied bays. Domestic sludges and sewage waste from industry, agriculture, and aquaculture practices impacted the metal concentration patterns in sediments and M. squalida. Similar to the conclusions reported by GóngoraGómez et al. (2018) for the pen shell A. maura, Cd and $\mathrm{Pb}$ burdens in the squalid callista clam exceeded the permissible limits for human consumption established by Mexican standards, posing a human health risk. Therefore, a continuous monitoring system is highly recommended and obligatory for the healthy production and consumption of this shellfish species.

\section{ACKNOWLEDGMENTS}

The authors thank the funding from Instituto Politécnico Nacional (IPN), through Secretaría de Investigación y Posgrado (SIP-20171303, SIP-20180655), Estímulo al Desempeño de los Investigadores (EDI), and Comisión de Operaciones y Fomento de Actividades Académicas (COFFA). Andrés Martín Góngora-Gómez, Hervey Rodríguez-González, Norma Patricia Muñoz-Sevilla, Brenda Paulina Villanueva-Fonseca, and Manuel García-Ulloa thank Sistema Nacional de Investigadores (SNI), Consejo Nacional de Ciencia y Tecnología (CONACyT), México. Carlos Humberto Sepulveda thanks CONACyT for the research fellowship. Thanks to Kristin Sullivan for English editing of the manuscript.

\section{REFERENCES}

Abdel-Ghani S.A. (2015). Trace metals in seawater, sediments, and some fish species from Marsa Matruh Beaches in north-western Mediterranean coast, Egypt. Egyptian J. Aqua. Res. 41 (2), 145-154. https://doi. org/10.1016/j.eraj.2015.02.006

Amezcua-Castro S., Ramírez-Rodríguez M., MedinaGómez S.P. and Gutiérrez-González J.L. (2015). Tendencias de producción de almeja chocolata Megapitaria squalida en Bahía Magdalena-Almejas, Baja California Sur, México. Ciencia Pesquera 23 (2), 3-10. 
Arellano-Martínez M., Quiñones-Arreola M.F., CeballosVázquez B.P. and Villalejo-Fuerte M. (2006). Reproductive pattern of the squalid callista Megapitaria squalida from northwestern Mexico. J. Shellfish Res. 25 (3), 849-855. https://doi.org/10.2983/0730$8000(2006) 25$

ATSDR (2006). Toxicological profile for cooper. Agency for Toxic Substances and Disease Registry [online]. http://www.atsdr.cdc.gov/toxprofiles/tp132.pdf $10 / 12 / 2018$

Barile F. (2008). Principles of toxicological testing. CRC Press. Boca Raton, FL, USA, 362 pp.

Bendell I.I. (2009). Survey of levels of cadmium in oysters, mussels, clams and scallops from the Pacific Northwest coast of Canada. Food Add. Contam. Part B 2 (2), 131-139. https://doi.org/10.1080/19440040903367765

Bray D.J., Green I., Golicher D. and Herbert R.J.H. (2015). Spatial variation of trace metals within intertidal beds of native mussels (Mytilus edulis) and non-native Pacific oysters (Crassostrea gigas): Implications for the food web? Hydrobiologia 757 (1), 235-249. https:// doi.org/10.1007/s10750-015-2255-8

Cantú-Medellín M., Olguín-Monroy N.O., Méndez-Rodríguez L.C. and Zenteno-Savín T. (2009). Antioxidant enzymes and heavy metal levels in tissues of the black chocolate clam Megapitaria squalida in Bahía de La Paz, Mexico. Arch. Environ. Contam. Toxicol. 56 (1), 60-66. https://doi.org/10.1007/s00244-008-9156-z

CCME (2003). Canadian Environmental Quality Guidelines. Canadian Council of Ministers of the Environment. [on line] https://www.ccme.ca/en/resources/canadian_environmental_quality_guidelines/02/10/2017

Coan E.V. and Valentich-Scott P. (2012). Bivalve seashells of tropical west America. Marine bivalve mollusks from Baja California to Peru. Santa Barbara Museum of Natural History. Santa Barbara, California, USA, $1223 \mathrm{pp}$.

Colín-Rangel G. (2007). Drenes Carrizo, Fuerte-Mayo. Ficha informativa de los humedales de RAMSAR (FIR) [online]. http://ramsar.conanp.gob.mx/docs/ sitios/FIR-RAMS/Sonora-Sinaloa.htm 12/11/2017

Cravo A., Foster P. and Bebianno M.J. (2002). Minor and trace elements in the shell of Patella aspera. Environ. Int. 28 (4), 295-302. https://doi.org/10.1016/S01604120(02)00038-7

Escobedo-Urías D.C. (2010). Diagnóstico y descripción del proceso de eutrofización en lagunas costeras del norte de Sinaloa. Ph.D. Thesis. Centro Interdisciplinario de Ciencias Marinas, Instituto Politécnico Nacional. La Paz, Baja California Sur, Mexico, 298 pp.

Ferreira G.A., Machado A.L.S. and Zalmon I.R. (2004). Temporal and spatial variation on heavy metal concentrations in the bivalve Perna perna (Linnaeus, 1758) on the Northern coast of Rio de Janeiro State, Brazil. Braz. Arch. Biol. Tech. 47 (2), 319-327.

Forrest B.M. and Creese R.G. (2006). Benthic impacts of intertidal oyster culture with consideration of taxonomic sufficiency. Environ. Monit. Assess. 112 (1-3), 159-176. https://doi.org/10.1007/s10661-006-0359-3

Frías-Espericueta M.G., Osuna-López J.L., Voltolina D., López-López G., Izaguirre-Fierro G. and Muy-Rangel M.D. (2008). The metal content of bivalve molluscs of a coastal lagoon of NW Mexico. Bull. Environ. Contam. Toxicol. 80 (1), 90-92. https://doi.org/10.1007/ s00128-007-9322-4

Frías-Espericueta M.G., Mejía-Cruz R., Osuna-López I., Muy-Rangel M.D., Rubio-Carrasco W., AguilarJuárez M. and Voltolina D. (2014). Metal discharges by Sinaloa rivers to the coastal zone of NW Mexico. Bull. Environ. Contam. Toxicol. 92 (2), 132-136. https://doi. org/10.1007/s00128-013-1158-5

García-Rico L., Ramos-Ruiz R.E. and Jiménez J.V. (2001). Determination of total metals in cultivated oysters (Crassostrea gigas) from the northwest coast of Mexico by microwave digestion and atomic absorption spectrometry. Journal of AOAC International 84 (6), 1901-1913.

Gaxiola C.L. (2003). Atlas de los ecosistemas de Sinaloa. El Colegio de Sinaloa. Culiacán Rosales, Sinaloa, Mexico, 481 pp.

Gómez-Arroyo S., Martínez-Valenzuela C., CalvoGonzález R., Villalobos-Pietrini R., Waliszewski S.M., Calderón-Segura M.E., Martínez-Arroyo A., Félix-Gastélum R. and Lagarda-Escárrega A. (2013). Assessing the genotoxic risk for Mexican children who are in residential proximity to agricultural areas with intense aerial pesticide application. Rev. Int. Contam. Ambie. 29 (3), 217-225.

Góngora-Gómez A.M., García-Ulloa M., Muñoz-Sevilla N.P., Domínguez-Orozco A.L., Villanueva-Fonseca B.P., Hernández-Sepúlveda J.A. and Ortega-Izaguirre R. (2017). Heavy-metal contents in oysters (Crassostrea gigas) cultivated on the southeastern coast of the Gulf of California, Mexico. Hidrobiológica 27 (2), 219-227. https://doi.org/10.24275/uam/izt/dcbs/ hidro/2017v27n2/Garcia

Góngora-Gómez A.M., Domínguez-Orozco A.L., Villanueva-Fonseca B.P., Muñoz-Sevilla N.P. and GarcíaUlloa M. (2018). Seasonal levels of heavy metals in soft tissue and muscle of the pen shell Atrina maura (Sowerby, 1835) (Bivalvia: Pinnidae) from a farm in the southeastern coast of the Gulf of California, Mexico. Rev. Inter. Contam. Ambie. 34 (1), 57-68. https://doi.org/10.20937/RICA.2018.34.01.05

Hernández-Cornejo R., Koedman N., Ruiz-Luna A., Troell M. and Dahgouh-Guebas F. (2005). Remote sensing 
and ethnobotanical assessment of the mangrove forest in the Navachiste-San Ignacio-Macapule lagoon complex, Sinaloa, Mexico. Ecol. Soc. 10 (1), 1-16.

Inengite A.K., Oforka N.C. and Osuji L.C. (2010). Survey of heavy metals in sediments of Kolocreek in the Niger Delta, Nigeria. African J. Environ. Sci. Tech. 4 (9), 558-566.

Jara-Marini M.E., Tapia-Alcazar J.N., Dumer-Gutiérrez J.A., García-Rico L., García-Hernández J. and PáezOsuna F. (2013). Comparative bioaccumulation of trace metals using six filter feeder organisms in a coastal lagoon ecosystem of the central-east Gulf of California. Environ. Monit. Assess. 185 (2): 10711085. https://doi.org/10.1007/s10661-012-2615-z

Jonathan M.P., Muñoz-Sevilla N.P., Góngora-Gómez A.M., Luna-Varela R.G., Sujitha S.B., Escobedo-Urías D.C., Rodríguez-Espinosa P.F. and Campos-Villegas L.E. (2017). Bioaccumulation of trace metals in farmed pacific oysters Crassostrea gigas from SW Gulf of California coast, Mexico. Chemosphere 187, 311-319. https://doi.org/10.1016/j.chemosphere.2017.08.098

Kanthai L.D., Gobin J.F., Beckles D.M., Lauckner B. and Mohammed A. (2014). Metals in sediments and mangrove oysters (Crassostrea rhizophorae) from the Canori Swamp, Trinidad. Environ. Monit. Assess. 186 (3), 1961-1976. https://doi.org/10.1007/s10661-013-3510-y

Kehrig H.A., Costa M., Moreira I. and Malm O. (2006). Total and methyl mercury in different species of molluscs from two estuaries in Rio de Janeiro state. J. Braz. Chem. Soc. 17 (7), 1409-1418. https://doi.org/10.1590/ S0103-50532006000700031

Lango-Reynoso F., Landeros-Sánchez C. and CastañedaChávez M.R. (2010). Bioaccumulation of cadmium $(\mathrm{Cd})$, lead $(\mathrm{Pb})$ and arsenic (As) in Crassostrea virginica (Gmelin, 1791), from Tamiahua lagoon system, Veracruz, Mexico. Rev. Int. Contam. Ambie. 26 (3), 201-210.

Liu W. and Deng P.Y. (2007). Accumulation of cadmium, cooper, lead \& zinc in the Pacific oyster, Crassostrea gigas, collected from the Pearl River estuary. Bull. Environ. Contam. Toxicol. 78 (6), 535-538. https:// doi.org/10.1007/s00128-007-9083-0

Luoma S.N. and Rainbow P. (2005). Why is metal bioaccumulation so variable? Biodynamics as a unifying concept. Environ. Sci. Tech. 39 (7), 1921-1931. https:// doi.org/10.1021/es048947e

Méndez L., Palacios E., Acosta B., Monsalvo-Spencer P. and Álvarez-Castañeda T. (2006). Heavy metals in the clam Megapitaria squalida collected from wild and phosphorite mine-impacted sites in Baja California, Mexico: Considerations for human health effects. Biol. Trace Elem. Res. 110 (3), 275-287. https://doi. org/10.1385/BTER:110:3:275
Mohammad S., Ibrahim R. and Mohamed S. (2017). Heavy metals and some nutritional elements in the Mediterranean carpet shell clam Donax semistriatus. Indian J. Geo Mar. Sci. 46 (6), 1145-1154.

Muñoz-Sevilla N.P., Villanueva-Fonseca B.P., GóngoraGómez A.M., García-Ulloa M., Domínguez-Orozco A.L., Ortega-Izaguirre R. and Campos-Villegas L.E. (2017). Heavy metal concentrations in diploid and triploid oysters (Crassostrea gigas) from three farms on the north-central coast of Sinaloa, Mexico. Environ. Monit. Assess. 189 (11), 536. https://doi.org/10.1007/ s10661-017-6223-9

Murray B.P. and Busty C.J. (2015). Epithermal mineralization controlled by synextensional magmatism in the Guzapares mining district of the Sierra Madre Occidental silicic large igneous province, Mexico. J. South Amer. Earth Sci. 58, 1-18. https://doi.org/10.1016/j. jsames.2014.12.009

Osuna-Martínez C.C., Páez-Osuna F. and Alonso-Rodríguez R. (2011). Cadmium, copper, lead and zinc in cultured oysters under two contrasting climatic conditions in coastal lagoons from the SE Gulf of California. Bull. Environ. Contam. Toxicol. 87 (3), 272-275. https://doi. org/10.1007/s00128-011-0355-3

Páez-Osuna F., Gracia A., Flores-Verdugo F., Lyle-Fritch L.P., Alonso-Rodríguez R., Roque A. and Ruiz-Fernández A.C. (1993). Biochemical composition of the oysters Crassostrea iridiscens Hanley and Crassostrea corteziensis Hertlein in the Northwest coast of Mexico: Seasonal changes. J. Exp. Mar. Biol. Ecol. 170 (1), 1-9. https://doi.org/10.1016/0022-0981(93)90125.8

Páez-Osuna F., Frías-Espiricueta M.G. and Osuna-López J.L. (1995). Trace metal concentrations in relation to season and gonadal maturation in the oyster, Crassostrea iridescens. Mar. Environ. Res. 40 (1), 19-31. https://doi.org/10.1016/0141-1136(94)00004-9

Páez-Osuna F., Gracia A., Flores-Verdugo F., Lyle-Fritch L. P., Alonso-Rodríguez R., Roque A. and RuizFernández A.C. (2003). Shrimp aquaculture development and the environment in the Gulf of California ecoregion. Mar. Poll. Bull. 46 (7), 806-815. https:// doi.org/10.1016/S0025-326X(03)00107-3

Páez-Osuna F. and Osuna-Martínez C.C. (2015). Bioavailability of cadmium, copper, mercury, lead, and zinc in subtropical coastal lagoons from the southeast Gulf of California using mangrove oysters (Crassostrea corteziensis and Crassostrea palmula). Arch. Environ. Contam. Toxicol. 68 (2), 305-3016. https://doi. org/10.1007/s00244-014-0118-3

Rainbow P.S. (2002). Trace metal concentrations in aquatic invertebrates: Why and so what? Environ. Poll. 120, 497-507. https://doi.org/10.1016/S02697491(02)00238-5 
Romo-Piñera A.K., Escobar-Sánchez O., Ruelas-Inzunza J. and Frías-Espericueta M. (2018). Total mercury in squalid callista Megapitaria squalida from the SW Gulf of California, Mexico: Tissue distribution and human health risk. Bull. Environ. Contam. and Toxicol. 100 (3), 356-360. https://doi.org/10.1007/ s00128-018-2271-2

Sally E.C., Michel S.J. and Richard T.L. (1996). Metal contamination of angler-caught fish from the Mersey Estuary. Mar. Environ. Res. 41, 281-297. https://doi. org/10.1016/0141-1136(95)00020-8

SEMARNAT (2007). Norma Oficial Mexicana NOM147-SEMARNAT/SSA1-2004. Que establece criterios para determinar las concentraciones de remediación de suelos contaminados por arsénico, bario, berilio, cadmio, cromo hexavalente, mercurio, níquel, plata, plomo, selenio, talio y/o vanadio. Secretaría de Medio Ambiente y Recursos Naturales. Diario Oficial de la Federación, Mexico, March 2.

Silvester F., Dorado J., Boltovskoy D., Juárez A. and Calado D. (2005). Filtration rates of the invasive pest bivalve Limnoperna fortunei as a function of size and temperature. Hydrobiologia 534 (1-3), 71-80. https:// doi.org/10.1007/s10750-004-1322-3

Soto-Jiménez M., Páez-Osuna F. and Morales-Hernández F. (2001). Selected trace metals in oysters (Crassostrea iridescens) and sediments from the discharge zone of the submarine sewage outfall in Mazatlan bay (southeast Gulf of California). Chemical fractions and bioaccumulation factors. Environ. Poll. 114 (3), 357370. https://doi.org/10.1016/s0269-7491(00)00239-6

SSA (1994). Proyecto de Norma Oficial Mexicana NOM109-SSA1-1994. Bienes y servicios. Procedimientos para la toma, manejo y transporte de muestras de alimentos para su análisis microbiológico. Secretaría de Salud. Diario Oficial de la Federación, Mexico, November 4.

SSA (1995). Norma Oficial Mexicana NOM-031SSA1-1993. Bienes y servicios. Productos de la Pesca. Moluscos bivalvos frescos-refrigerados y congelados. Especificaciones sanitarias. Secretaría de Salud. Diario Oficial de la Federación, Mexico, March 3.

SSA (2011). Norma Oficial Mexicana NOM-242SSA-1-2009. Productos y servicios. Productos de la pesca frescos, refrigerados, congelados y procesados. Especificaciones sanitarias y métodos de prueba. Secretaría de Salud. Diario Oficial de la Federación, Mexico, February 10.

Tarique Q., Burger J. and Reinfelder J.R. (2012). Metal concentrations in organs of the clam Amiantis umbonella and their use in monitoring metal contamination of coastal sediments. Water, Air Soil Poll. 223, 21252136. https://doi.org/10.1007/s11270-011-10009-0

Thomann R.V., Mahony J.D. and Mueller R. (1995). Steady state model of biota-sediment accumulation factor for metals in two marine bivalves. Environ. Toxicol. Chem. 14 (11), 1989-1998. https://doi.org/10.1002/ etc. 5620141121

USEPA (2001). EPA 823-B-01-002. Methods for collection, storage and manipulation of sediments for chemical and toxicological analyses: Technical Manual. Office of Water, United States Environmental Protection Agency. Washington, D.C., USA, 208 pp.

Vázquez-Boucard C., Anguiano-Vega G., Mercier L. and Rojas del Castillo E. (2014). Pesticide residues, heavy metals, and DNA damage in sentinel oysters Crassostrea gigas from Sinaloa and Sonora, Mexico. J. Toxicol. Environ. Health 77 (4), 169-176. https:// doi.org/10.1080/15287394.2013.853223

WHO (1996). Trace elements in human nutrition and health. World Health Organization. Geneva, Italy, $360 \mathrm{pp}$.

Widmeyer J.R. and Bendell-Young L.I. (2008). Heavy metal levels in suspended sediments, Crassostrea gigas, and the risk to humans. Arch. Environ. Cont. Toxicol. 55 (3), 442-450. https://doi.org/10.1007/ s00244-007-9120-3

Wong C.S.C., Wu S.C., Duzgoren-Aydin N.S., Aydin A. and Wong M.H. (2007). Trace metal contamination of sediments in an e-waste processing village in China. Environ. Poll. 145 (2), 434-442. https://doi. org/10.1016/j.envpol.2006.05.017

Yee-Duarte J.A., Ceballos-Vázquez B.P., Shumilin E., Kidd K. and Arellano-Martínez M. (2017). Evidence of health impairment of Megapitaria squalida (Bivalvia: Veneridae) near the "hot spot" of a mining port, Gulf of California. Hidrobiológica 27 (3), 391-398. https:// doi.org/10.24275/uam/izt/hidro/2017v27n3/Arellano 